\title{
Cytotoxic effect of hydroalcoholic extract of Annona Muricata against a human cell line of gastric adenocarcinoma
}

\author{
Efecto citotóxico del extracto hidroalcoholico de la \\ Annona Muricata frente a la línea celular humana de \\ adenocarcinoma gástrico
}

Paola Natalia Alvarado Mayor ${ }^{1}\left(\mathbb{D}\right.$, Alexandra Bautista-Flores ${ }^{1 *}$, Amanda Asunción Lovera Arellano' ${ }^{10}$

JOURNAL VITAE

School of Pharmaceutical and Food Sciences

ISSN 0121-4004 | ISSNe 2145-2660

University of Antioquia

Medellin, Colombia

Filliations

${ }^{1}$ Universidad Científica del Sur, Lima, Perú

*Corresponding Alexandra Bautista-Flores 100027015@cientifica.edu.pe

Received: 23 November 2021 Accepted: 23 January 2022 Published: 15 February 2022

\begin{abstract}
Background: Therapeutic advances against cancer have not been as successful as expected and have adverse effects that patients rarely tolerate. A study in Peru identified favorable anticancer effects of Annona muricata (AM), a medicinal plant known as soursop, in C-678 mouse gastric adenocarcinoma. However, to date, no results have been reported in human cells. Objective: The objective of this study was to determine the cytotoxic effect of AM extract against a human gastric adenocarcinoma cell line (AGS). Methodology: Experimental in vitro analytical study using a hydroalcoholic extract of $A M(A M O H)$ leaves collected in the Amazonas. Chemical functional groups were identified by phytochemical screening. To obtain the cytotoxic effect, different dilutions of extract were added to the plates containing the cell lines and the data were extrapolated to GraphPad employing an observation card. Finally, the cytotoxic effect was expressed as the half-maximal inhibitory concentration $\left(I C_{50}\right)$ and nonlinear regression analysis was performed to determine the growth inhibition of cancer cells. Results: Phytochemical screening showed the presence of reducing carbohydrates, alkaloids, phenols, tannins, triterpenes, steroids, saponins, flavonoids, proteins, cardiac glycosides, and anthocyanins. A calibration curve with gallic acid was used to determine the total phenol content and, quercetin was used to identify the flavonoid content. The AGS cell line showed cytotoxic activity with AMOH with an IC50 at 24 hours of $45.81 \mu \mathrm{g} / \mathrm{mL}$ and $19.05 \mu \mathrm{g} / \mathrm{mL}$ at 48 hours. Conclusion: Several chemical functional groups of AM were identified. In addition, the $\mathrm{AMOH}$ showed a cytotoxic effect against the AGS cell line.
\end{abstract}

Keywords: Cancer; stomach; Annona muricata; cytotoxicity; hydroalcoholic extract 


\section{RESUMEN}

Antecedente: Los avances terapéuticos frente al cáncer no han tenido el éxito esperado y presentan efectos adversos pocas veces tolerados por el paciente. Un estudio en Perú identificó el efecto anticancerígeno de la Annona muricata (AM), planta medicinal conocida como guanábana, en adenocarcinoma gástrico de ratón C-678 con resultados favorables, sin embargo, no se ha encontrado evidencia previa en células humanas. Objetivo: El objetivo de este estudio fue determinar el efecto citotóxico del extracto de AM frente a la línea celular de adenocarcinoma gástrico humano (AGS). Materiales y métodos: Estudio experimental in vitro tipo analítico con extracto hidroalcohólico de hojas de AM (AMOH) recolectadas en Amazonas. Mediante screening fitoquímico se identificaron los grupos funcionales químicos. Para obtener el efecto citotóxico, se añadieron diferentes diluciones de extracto a las placas que contienen las líneas celulares y mediante una ficha de observación los datos fueron extrapolados a GraphPad. Finalmente se expresó como la concentración inhibitoria media máxima (IC50) y se hizo un análisis de regresión no lineal con la finalidad de encontrar la cantidad de inhibición de crecimiento de células oncológicas.

Resultados: En el screening fitoquímico se pudo identificar la presencia de carbohidratos reductores, alcaloides, fenoles, taninos, tritérpenos y esteroides, saponinas, flavonoides, proteínas, glicósidos cardiotónicos y antocianinas. Para identificar el contenido total de fenoles se utilizó la curva de calibración con ácido gálico el cual nos comprobó la presencia de una buena cantidad de estos metabolitos. Adicionalmente se utilizó quercetina para identificar el contenido de flavonoides, obteniendo resultados favorables ya que se hizo evidente su presencia. La línea celular AGS mostró una actividad citotóxica frente al AMOH con un IC50 a las 24 horas de $45.81 \mathrm{ug} / \mathrm{mL}$ y $19.05 \mathrm{ug} / \mathrm{mL}$ a las 48 horas. Conclusión: Se identifica a los grupos funcionales de la AM. Además, AMOH demostró un efecto citotóxico contra la línea celular AGS.

Palabras claves: Cáncer; estómago; Annona muricata; citotoxicidad; extracto hidroalcoholico

\section{INTRODUCTION}

According to the National Cancer Institute, cancer is one of the leading causes of deaths worldwide (1). The incidence of gastric cancer in Peru is 15.2 per 100,000 inhabitants, being the highest value in all Latin America: Haiti (13.5), Chile (13.0), Colombia (12.8), and Costa Rica (12.8). However, this value is surpassed by Asian countries such as Mongolia (32.5), Japan (31.6), and South Korea (27.9) (2). The 5 -year survival of gastric cancer is less than $27 \%$, and it has been estimated that in 2030 it will cause the death of 1.4 million individuals (3).

Annona Muricata (AM) is a medicinal plant belonging to the class Equisetopsida C. Agardhy and subclass Magnoliidae Novák ex Takht (4) and is commonly known as soursop (5). It has been studied for its therapeutic potential and the medicinal properties produced by its secondary metabolites synthesized and located in different parts of the plant (6). Among its various bioactive components, annonaceous acetogenins have anti-proliferative effects and, therefore, potential anti-cancer properties $(7,8)$. These components predominate in the leaves and shell; their extract is being used to search for anticancer properties (9).

The objective of cancer treatment is to inhibit the growth of cancer cells. However, some treatments can damage healthy cells leading to adverse effects that can compromise the patient's life or do not produce the expected results $(10,11)$. Moreover, these adverse effects can cause greater susceptibility to infections, anemia, neuropathies such as numbness and tingling, decreased mental function, and heart damage (12). To date, many articles have been published on medicinal plants to combat this disease and control its adverse effects (13). According to the World Health Organization (WHO), traditional medicine can reduce costs and be accessible for low-income populations (14).

A preclinical study in mice demonstrated the protective effects of the hydroalcoholic extract of AM on the gastric mucosa reducing the ulceration process by activating prostaglandins and reducing aggressive factors (15). In addition, the cytotoxic effect of the ethanolic extract of AM has been studied in the mouse gastric adenocarcinoma cell line C-678, obtaining favorable results (16). However, no previous study has demonstrated this activity in human gastric adenocarcinoma cells.

Despite the wealth of 5,000 different species of plants that can be used in multiple ways to treat various ailments and consumed as therapy even before approaching a health institution $(17,18)$, there are very few studies demonstrating the real utility of these plants.

Taking all the above into account, the main objective of this study was to determine the cytotoxic effect of AM hydroalcoholic extract ( $\mathrm{AMOH}$ ) and determine the chemical functional groups and the half-maximal inhibition concentration $\left(\mathrm{IC}_{50}\right)$ against a human gastric adenocarcinoma cell line (AGS). 


\section{MATERIALS AND METHODS}

We performed an analytical, prospective in-vitro experimental study, as part of a pre-clinical trial design including the AGS cell line.

\section{Preparation of the hydroalcoholic extract from AM}

The AM leaves were collected in Alto Amazonas, Bagua and identified at the Centro Nacional de Salud Intercultural of Instituto Nacional de Salud (CENSI/INS). Two hundred grams of leaves were weighed in powder, and 1,500 mL of alcohol $70^{\circ}$ were added to the sample and allowed to macerate for 14 days. Then the mix was filtered and reduced to $40^{\circ}$ with $20 \mathrm{rpm}$ and $70 \mathrm{mbar}$ in a rotary evaporator RV10C $\left(I K A^{\circledR}\right)$ to obtain a resin. The data was collected on an observation sheet (Table 1).

\section{Solubility assay}

Methanol, ethanol, chloroform, N-hexane, ethyl acetate, and distilled water were added to $50 \mathrm{mg}$ of the dry drug in a proportion of $1 \mathrm{~mL}$ to each test tube to determine the solubility of the active components of the sample (19) (Table 2, Figure 1).

\section{Phytochemical screening}

Phytochemical screening of the resin of the $\mathrm{AMOH}$ was carried out to identify the chemical functional groups (Table 3, Figure 2).

\section{Determination of the total phenolic content in hydroalcoholic extract}

Total phenols were determined by the FolinCiocalteu method using gallic acid as a reference standard (20). $21.4 \mathrm{mg}$ of the resin was weighed, and a mix of dimethyl sulfoxide (DMSO) and ultrapure water (1:1) was used for resuspension. $100 \mu \mathrm{L}$ of the sample was taken and diluted in $900 \mu \mathrm{L}$ of ultrapure water, and the reaction system was performed. The sample was treated three times; $1 \mathrm{~mL}$ of FolinCiocalteau and $0.1 \mathrm{~mL}$ of $\mathrm{AMOH}$ were added to each sample and set for 5 minutes. Then $1 \mathrm{~mL}$ of $7.5 \%$ sodium carbonate was added and the sample was placed in a water bath at $45^{\circ}$ for 15 minutes. Finally, it was read at $725 \mathrm{~nm}$ in a UV/VIS Pharo 300 spectrophotometer (Spectroquant ${ }^{\circledR}$ ) (Table 4).

\section{Determination of flavonoids in hydroalcoholic extract}

The flavonoids content was determined in AM using quercetin as a reference standard (21). 51 mg of the resin was weighed, and a mix of resin and $96 \%$ of ethanol was used for the resuspension with a 1:10 solution to perform the reaction system. Three sets of test tubes were prepared and read at $255 \mathrm{~nm}$ in a UV/VIS Pharo 300 spectrophotometer (Spectroquant $\AA$ ). A solution of $0.0051 \mathrm{~g}$ of quercetin was prepared for the calibration curve in $50 \mathrm{~mL}$ of ethanol $96^{\circ}$. The following concentrations were prepared from this stock solution: 1, 5, and 10 ppm (Table 4).

\section{Oncology cell line}

The AGS cell line of the European Authenticated Cell Culture Collection (ECACC 89090402) was cultured in Dulbecco's modified Eagle medium supplemented with $10 \%$ of fetal bovine serum and $1 \%$ antifungal antibiotic on a stove with $\mathrm{CO} 2 / 95 \%$ and $5 \%$ of moisture at $37^{\circ} \mathrm{C}$ for 24 hours (Figure 3 ).

\section{Cytotoxic effect}

The $\mathrm{AMOH}$ dilutions were calculated from a laboratory stock concentration of $32 \mathrm{mg} / \mathrm{mL}$ dimethyl sulfoxide (DMSO) stored at $-80^{\circ} \mathrm{C}$. The human gastric adenocarcinoma cells were counted in the Neubauer chamber (5x103 cells) and placed in a 96-well plate. All the cells were incubated for 12 hours and then 20,40,80, and $160 \mu \mathrm{g} / \mathrm{mL}$ of $\mathrm{AMOH}$ were added. Morphological changes were microscopically observed and photographed (Nikon Eclipse $\mathrm{TI}^{\circledR}$ ) after further incubation for 24 and 48 hours. A control group to which 0.5\% DMSO was added without the extract was also used. $20 \mu \mathrm{L}$ of resazurin was added to the wells, and the sample was incubated again for 3 hours to determine cell viability at a concentration of $0.15 \mathrm{mg} / \mathrm{mL}$. Finally, the plate was read by a Synergy LX spectrophotometer $\left(\right.$ Biotek $^{\circledR}$ ) with 570 and 600 nm (Figure 4).

\section{Statistical analysis}

Data obtained from cellular viability absorbance were extrapolated to Microsoft Excel and expressed in percentages considering the control group. Regarding the cytotoxic effect, the response to the different doses and the $\mathrm{IC}_{50}$ were determined by non-linear regression analysis. Significant differences among values were compared with the one-way ANOVA test with post hoc of Tukey test $(p<0.05)$, using GraphPad Prism 5 Project software (Figure 5). 


\section{RESULTS}

Table 1. Observation sheet of hydroalcoholic extract of Annona Muricata

\begin{tabular}{|l|l|}
\hline \multicolumn{2}{|c|}{ Hydroalcoholic extract of Annona Muricata } \\
\hline Initial amount & $1500 \mathrm{~mL}$ of $70^{\circ}$ alcohol and $200 \mathrm{~g}$ of AM \\
Final amount & $32 \mathrm{gr}$ of resin \\
Yield percentage & $16 \%$ \\
\hline
\end{tabular}

Table 2. Results of solubility assay of the resin of Annona Muricata

\begin{tabular}{|l|l|}
\hline \multicolumn{1}{|c|}{ Solvent } & Results \\
\hline Methanol & ++++ \\
Chloroform & +++ \\
Ethyl acetate & - \\
$\mathrm{N}$ hexane & - \\
Ethanol 70\% & ++ \\
Distilled water & ++ \\
\hline
\end{tabular}

Legend: ++++ : very soluble, +++ : soluble in medium proportion, + : soluble in low proportion, -: absent

\section{Figure 1. Solubility assay}

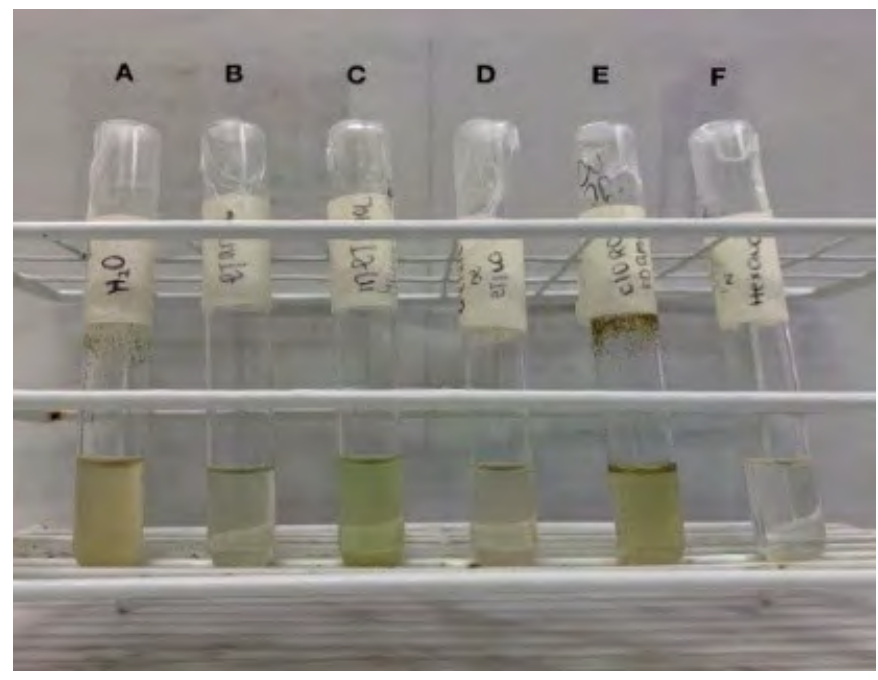

Figure 1. A: distilled water, B: ethanol, C: methanol, D: ethyl acetate, E: chloroform, F: n-hexane

The results of the phytochemical screening are shown in Table 3 and Figure 2 according to the group of metabolites identified.

Table 3. Phytochemical screening of fresh leaves of Annona Muricata.

\begin{tabular}{|l|c|c|c|}
\hline \multicolumn{1}{|c|}{ Metabolite } & Reactive & Indicator & Results \\
\hline Free amino acids & Ninhydrin & Coloration & $(--)$ \\
\hline \multirow{2}{*}{ Carbohydrates (reducing sugar) } & Benedict & Coloration & $(++)$ \\
\cline { 2 - 4 } & Fehling & Coloration & $(++)$ \\
\hline \multirow{2}{*}{ Alkaloids } & Dragendorff & Coloration & $(++)$ \\
\cline { 2 - 4 } & Wagner & Precipitation & $(++)$ \\
\hline Phenols and Tannins & Ferric trichloride & Coloration & $(++)$ \\
\hline Triterpenes and steroids & Liberman-Buchard & Coloration & $(++)$ \\
\hline Saponins & Foam test & Foam & $(++)$ \\
\hline Quinones & Borntrager & Coloration & $(--)$ \\
\hline Flavonoids & Shinoda & Coloration & $(++)$ \\
\hline Catechins & Sodium carbonate & Coloration & $(--)$ \\
\hline Proteins & Biuret & Coloration & $(++)$ \\
\hline Tannins & Gelatin & Precipitation & $(++)$ \\
\hline Cardiotonic Glycosides & Kedde & Coloration & $(++)$ \\
\hline Anthocyanin & Anthocyanin & Coloration & $(++)$ \\
\hline Resin & H ${ }_{2} 0$ & Precipitation & $(--)$ \\
\hline
\end{tabular}

(++) Positive, (- -) negative 


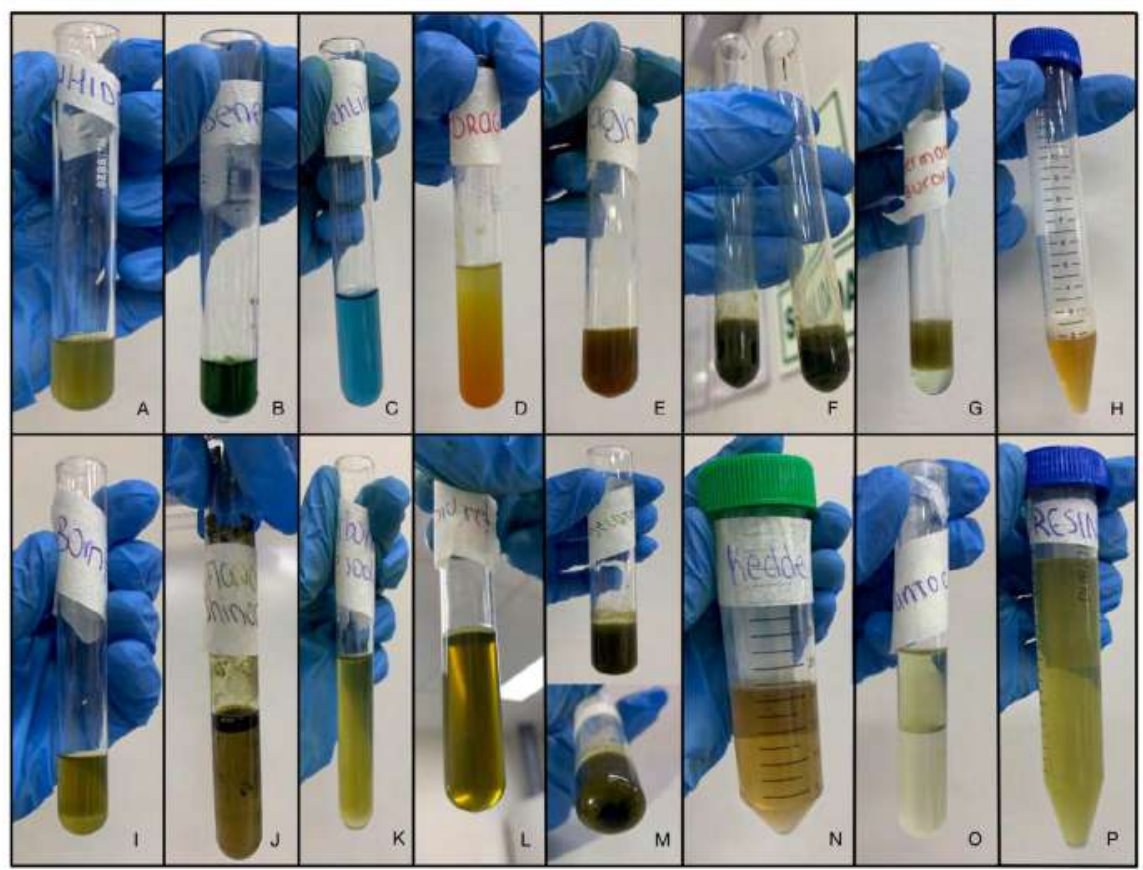

Figure 2. Phytochemical screening. A: Ninhydrin, B: Benedict, C: Fehling, D: Dragendorff, E: Wagner, F: Ferric trichloride G: LibermanBuchard, H: Foam test, I: Borntrager, J: Shinoda, K: Sodium carbonate, L: Biuret, M: Gelatin, N: Kedde, O: Anthocyanin, P: Resin.

The phenolic compound content in $\mathrm{AMOH}$ is shown in Table 4, expressed as mg of gallic acid.

Table 4. Total phenolic and flavonoid content

\begin{tabular}{|c|c|}
\hline $\begin{array}{c}\text { Flavonoid content (mg/g of } \\
\text { flavonoids sample equivalent } \\
\text { to quercetin) }\end{array}$ & $\begin{array}{c}\text { Phenolic content (mg/g of po- } \\
\text { lyphenols sample equivalent } \\
\text { to gallic acid) }\end{array}$ \\
\hline $0.249 \mathrm{mg} / \mathrm{g}$ & $1.013 \mathrm{mg} / \mathrm{g}$ \\
\hline
\end{tabular}

\section{Cell morphology}

Changes were observed in both cell morphologies. At 24 hours, at a $20 \mu \mathrm{g} / \mathrm{mL}$ concentration, some cells were suspended while others adhered at 24 hours, becoming more notable with the cells being amorphous and fragmented at higher concentrations of 40,80 , and $160 \mu \mathrm{g} / \mathrm{mL}$. At 48 hours, the effect was much greater, with fragmented cells being observed at the minimum concentration $(20 \mu \mathrm{g} / \mathrm{mL})$ (Figure 3$)$.

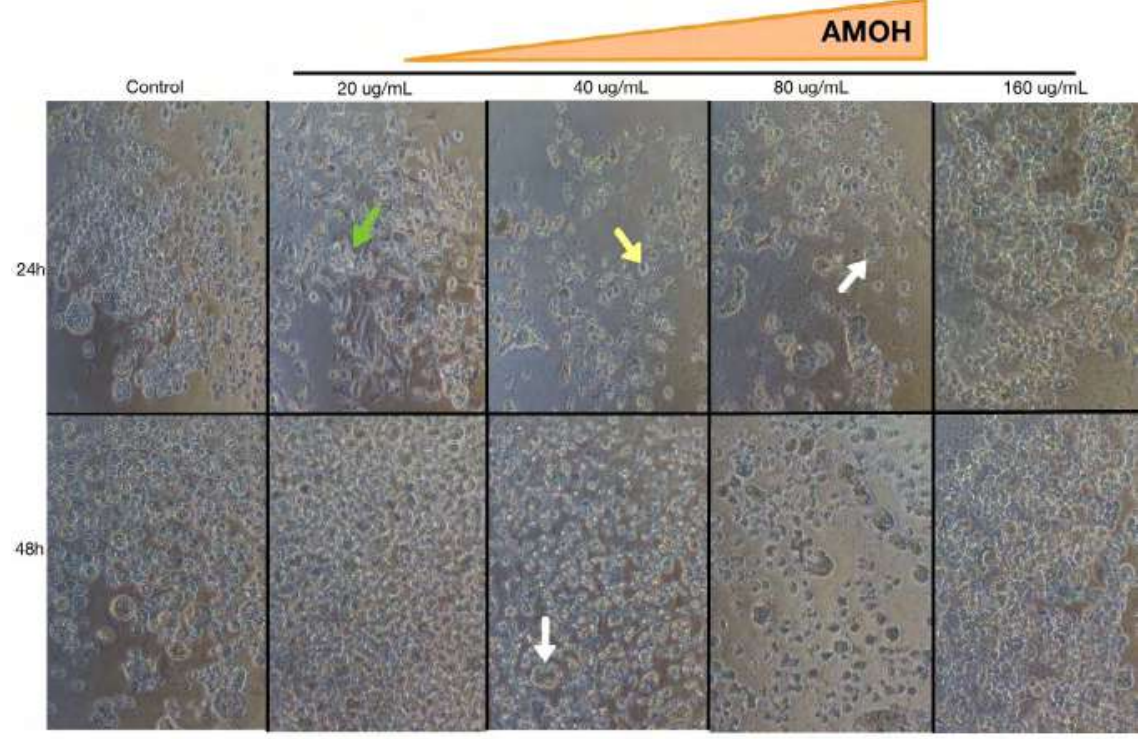

Figure 3. Effect of the hydroalcoholic extract of Annona muricata on the morphology of the AGS cell line at 20,40,80 and $160 \mu \mathrm{g} /$ $\mathrm{mL}$ observed at 100X. The control group of cells without extract but with the vehicle (DMSO $0.5 \%$ ) is shown. 


\section{Cytotoxic effect}

The AGS cell line showed cytotoxic activity to $\mathrm{AMOH}$ with an $I_{50}$ at 24 hours of $45.81 \mu \mathrm{g} / \mathrm{mL}$ and $19.05 \mu \mathrm{g} /$ $\mathrm{mL}$ at 48 hours (Figure 4). No significant difference was obtained between the cellular control and the response to $20 \mu \mathrm{g} / \mathrm{mL}$ of the extract, with the same being observed for $80 \mu \mathrm{g} / \mathrm{mL}$ versus $160 \mu \mathrm{g} / \mathrm{mL}$. However, significant differences were observed with the remaining concentrations at 24 hours. At 48 hours, a significant value was obtained between the cellular control and the different concentrations: 20 , 40,80 , and $160 \mu \mathrm{g} / \mathrm{mL}$, with no significant difference among the remaining concentrations (Figure 5).

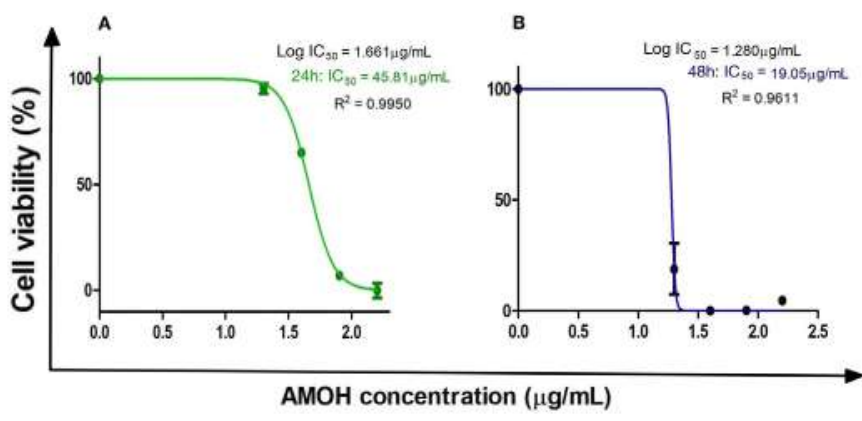

Figure 4. Cytotoxic effect of the hydroalcoholic extract of Annona Muricata (AMOH) on cell viability. The AGS cell line was treated at different concentrations of $\mathrm{AMOH}(20,40,80$, and $160 \mu \mathrm{g} / \mathrm{mL}$ ) for 24 and 48 hours. The IC50 graphs are shown with a log10 dependent on the cell viability curve of the $\mathrm{AMOH}$ concentration $(\mu \mathrm{g} / \mathrm{mL})$.

AMOH: Hydroalcoholic extract of Annona Muricata, $\mathrm{IC}_{50}: 50 \%$ cell inhibition concentration, R2: Coefficient of determination of the non-linear regression model.

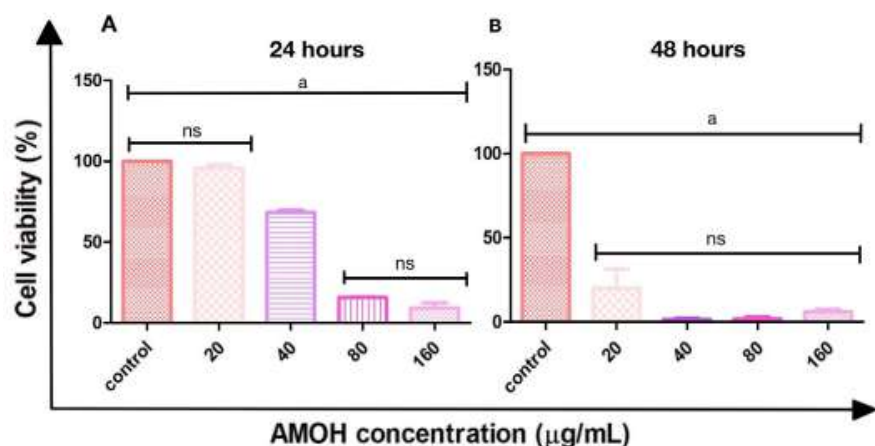

Figure 5. Comparison of cell viability (\%) at the different concentrations of the Annona Muricata extracts at 24 and 48 hours.

ns: not significant, a: $p<0.05$

\section{DISCUSSION}

One of the most important and interesting aspects of our study was determining the chemical and functional groups of $A M$ in the cytoplasm of the plant cell.
The Shinoda reaction was used to identify flavonoids showing a positive faint yellow coloration. Flavonoids have antioxidant activity thanks to a combination of their properties that sequester free iron and chelators, protecting against inflammation. In addition, the flavonoid compounds protect against the formation of malignant tumors, reduce the risk of developing heart disease, and have an antiviral and antibacterial effect (22-24). Alkaloids were identified using the Dragendorff reaction showing a brownishorange precipitate. The pharmacological spectrum of alkaloids was wide, and the pharmacological properties of these compounds include modification of the nervous system and analgesic, anticancer and antimicrobial activities (25-27). The presence of tannins and phenols was confirmed using the reaction of ferric trichloride, presenting a grayishgreen color, identifying the presence of adjacent $2-\mathrm{OH}$. The defining characteristic of tannins is their astringent capacity, and they are commonly used to treat flu symptoms and bronchitis. They also have pharmacological applications as antimicrobials, antifungals, and antidiarrheals and are used as an antidote for heavy metals. On the other hand, phenols have a long list of properties, the main properties being: antioxidant, anti-allergic, antitumoral, and antiasthma, among others (28). The use of the Liebermann-Burchard test allowed identification of triterpenes and steroids, showing an instantaneous change in coloration. These compounds have anti-inflammatory, anti-tumoral, and antiviral activities (29). The presence of peptides and/or proteins was identified by a purple-violet coloration using the Biuret test. These compounds are usually used in patients with stomach disorders, such as infants with malabsorption malnutrition syndrome (30). The use of the foam test identified the presence of both steroid and tripterpenic saponins, for which expectorant, diuretic, and hemolytic actions have been described (27-31). The Kedde reaction identified cardiotonic glycosides related to cytotoxic activity (32). Anthocyanins, which are strong antioxidants, were the last metabolite identified (33). Finally, negative results were obtained for quinones and resin. The presence and absence of all the compounds studied have been corroborated in 6 previous studies in various countries including Brazil, Peru, Venezuela, and Colombia (34-40).

The absence of free amino acids and catechins, which have several medicinal properties, was of note, despite having been reported in previous studies $(41,42)$. Amino acids have regulatory 
functions in health, such as maintaining immune, gastric, neuromuscular, and cognitive protective functions (43). In the case of catechins, these are excellent antioxidants, help in weight control, prevent cardiovascular diseases, and have anticancer activity (44).

On the other hand, reducing carbohydrates' presence is unclear since some studies have identified them but not in others. This can be explained by the extract studied; for example, methanol extracts show greater solubility of chemical compounds than ethanolic extracts. In our study, these carbohydrates are related to their high presence in the plant (45).

In the present study, AMOH showed potent cytotoxic activity against the AGS cell line confirmed by our negative control (DSMO 10\%). The $I_{50}$ at 24 hours was $45.81 \mu \mathrm{g} / \mathrm{mL}$ and $19.05 \mu \mathrm{g} / \mathrm{mL}$ at 48 hours, showing greater cytotoxic activity in vitro at 48 hours. The anti-tumor activity of AM has been studied in various cell lines, showing its cytotoxic activity against breast, prostate, liver, endometrial, skin, colorectal cancer, and hematological neoplasms (46). However, the cytotoxic potential against AGS was evidenced for the first time in this study. This finding is important considering that currently, the regions with the highest mortality per 100,000 inhabitants in Peru are Huánuco $(21,7)$; Huancavelica $(17,7)$, and Junín $(16,8)$, which have a high poverty index and less access to health services, and thus, easy access to this plant could be beneficial (47). Cytotoxic effects of different treatments have been widely studied in different types of cancer and are due to different mechanisms, such as: stimulation of apoptosis through mitochondrial damage, proteins that stop the cell cycle in the G0, G1, and G2 phases, and an increase in the cleavage of caspase-3, with anti-proliferation effects (46). Further studies on the mechanisms inducing cytotoxic effects in gastric cancer are needed.

Additionally, the anti-tumor activity of $\mathrm{AMOH}$ can be explained by the total phenol content identified in the present study. In vitro studies have shown that polyphenols have antioxidant effects and can delay or inhibit the oxidation of other molecules making the initiation or propagation of free radical chain reactions impossible and demonstrating their relationship with the anti-proliferative activity of cancer cells (48). Similarly, flavonoids were identified as part of total phenol content using quercetin as a reference, and together these polyphenols enhance the anticancer effects of $\mathrm{AMOH}$.

\section{CONCLUSIONS}

AM has chemical functional groups such as flavonoids, reducing carbohydrates, alkaloids, phenols, tannins, triterpenes, steroids, saponins, proteins, cardiotonic glycosides, and anthocyanins with medicinal properties. The cytotoxic effect of $\mathrm{AMOH}$ was demonstrated against the AGS cell line with an IC50 of $45.81 \mu \mathrm{g} / \mathrm{mL}$ at 24 hours, achieving the highest effect of $19.05 \mu \mathrm{g} / \mathrm{mL}$ at 48 hours, demonstrating that the effect was maintained. This effect can be explained by metabolites with anticancer properties, mainly phenols, and flavonoids, identified in the present study. Further studies are needed to determine the mechanisms inducing this effect.

\section{CONFLICT OF INTEREST}

The authors declare no conflict of interest.

\section{ACKNOWLEDGMENTS}

We thank the cell culture and natural product laboratory of the Universidad Científica del Sur, and especially Dr. Ana Mayanga Herrera, Salyoc Tapia Rojas, and Roxana Ramos Aramburu who supported us in carrying out the project.

\section{AUTHOR CONTRIBUTIONS}

All the authors discussed the results, contributed to the final manuscript, and assume responsibility for the content of the manuscript.

\section{REFERENCES}

National Cancer Institute, Cancer statistics. https://www.cancer. gov/about-cancer/understanding/statistics 2015 (accessed 28 October 2021).

GLOBOCAN, Cancer today. https://gco.iarc.fr/today/about 2020 (accessed 28 October 2021).

National Cancer Institute, SEER Cancer Statistics Review (CSR) 1975 2018. https://seer.cancer.gov/csr/1975_2018/2021 (accessed 28 October 2021).

Tropicos, Annona Muricata. https://www.tropicos.org/name/1600001 (accessed 28 October 2021).

Ortiz-Septién G, Campos-Ortiz S. Healing properties of soursop (annonamuricata) leaves and theirpotential pharma-industrial impact [Grade work]. [Puebla, Mexico]: Universidad Autonoma de Puebla: 2018. 12p.

Gavamukulya Y, Wamunyokoli F, El-Shemy HA. Annona muricata: Is the natural therapy for most disease conditions including cancer growing in our backyard? A systematic review of its research history and future prospects. Asian Pacific Journal of Tropical 
Medicine. 2017;10(9):835-848. DOI: https://doi.org/10.1016/j apjtm.2017.08.009

Yang C, Gundala SR, Mukkavilli R, Vangala S, Reid MD, Aneja R. Synergistic interactions among flavonoids and acetogenins in Graviola (Annona muricata) leaves confer protection against prostate cancer. Carcinogenesis. 2015;36(6):656-65. DOI: https:// doi.org/10.1093/carcina/bgv046

Bermúdez, Alexis, Oliveira-Miranda, María A., Velázquez, Dilia. La investigación etnobotánica sobre plantas medicinales: una revisión de sus objetivos y enfoques actuales. Interciencia [Internet]. 2005 [cited 2021 Oct 28] ;30(8):453-459. Available from: https://www.redalyc.org/articulo.oa?id=33910703

Rodríguez Lado DC, Sori Díaz Y, Barceló Tellería JA. Necesidad de un protocolo integrado de Medicina Natural y Tradicional dirigido al paciente oncológico. Medicentro Electrónica [Internet]. 2019 Mar [cited 2021 Oct 28];23(1):75-8. Available from: http:// scielo.sld.cu/scielo.php?script=sci_arttext\&pid=S102930432019000100014\&lng=es\&nrm=iso

Arnanz Velasco F, Calderay Domínguez M, Córdoba Largo S, Crespo Massieu C, Fuentes Castro P, González Martín A, et al. Cáncer de mama. Temas actuales, Ergon, Madrid; 2008. 240p

Loraine S, Alberto M-EJ. Medicinal plants as potential agents against cancer, relevance for Mexico. Revista Mexicana de Ciencias Farmaceuticas [Internet]. 2010 [cited 2021 Oct 28];41(4):18-27. Available from: https://www.redalyc.org/ articulo.oa?id $=57916060003$

Smith RA, Andrews K, Brooks D, et al. Cancer screening in the United States, 2016: A review of current American Cancer Society guidelines and current issues in cancer screening. CA Cancer J Clin. 2016;66(2):96-114. DOI: https://doi. org/10.3322/caac.21336

Llopart Carles N. Las plantas medicinales como fuente de compuestos antineoplásicos. [Grade work]. [Madrid, España]: Universidad Complutense: 2016. 25p.

World Health Organization, Estrategia de la OMS sobre medicina tradicional 2014-2023. https://apps.who.int/iris/ bitstream/handle/10665/95008/9789243506098_spa.pdf 2013 (accessed 28 October 2021).

Bento EB, Júnior FE de B, de Oliveira DR, Fernandes CN, de Araújo Delmondes G, Cesário FRAS, et al. Antiulcerogenic activity of the hydroalcoholic extract of leaves of Annona muricata Linnaeus in mice. Saudi Journal of Biological Sciences. 2018;25(4):609-2. DOI: https://doi.org/10.1016/j. sjbs.2016.01.024

Quispe A, Zavala D, Posso M, Rojas J, Vaisberg A. Efecto citotóxico de Annona muricata (guanabana) en cultivo de líneas celulares de adenocarcinoma gástrico y pulmonar. CIMEL Ciencia e Investigación Médica Estudiantil Latinoamericana [Internet] 2007 [cited 2021 Oct 28];12(1):19-22. Available from: https://www.redalyc. org/pdf/717/71712105.pdf

Egg AB. Diccionario enciclopédico de plantas útiles del Perú. Programa de las Naciones Unidas para el Desarrollo, Texas; 1999. 588p.

Galvez JAM, R EC, R JLM, S SAF. Conocimiento, aceptación y uso de medicina tradicional peruana y de medicina alternativa/complementaria en usuarios de consulta externa en Lima Metropolitana. Revista Peruana de
Medicina Integrativa. 2017;2(1):47-57. DOI: http://dx.doi. org/10.26722/rpmi.2017.21.44

Lozano R. N, Solís Q. L, Bonilla R. P. Sustancias químicas bioactivas de la Peperomia flavamenta. Ciencia e investigación [Internet]. 1998 June [cited 2021 Oct 28];1(1):32-4. Available from: https://revistasinvestigacion. unmsm.edu.pe/index.php/farma/article/view/4749

Marina D, Avella G, Alberto C, García O, Cisneros A. Medición de Fenoles y Actividad Antioxidante en Malezas Usadas para Alimentación Animal. Centro Nacional de Metrología [Internet]. 2008 [cited 2021 Oct 28]; Available from: https:// www.semanticscholar.org/paper/Medici\%C3\%B3n-deFenoles-y-Actividad-Antioxidante-en-Marina-Avella/ f41204d2a19ab71734cff45f1bfdaa11267f043c

Colina Ramos AC. Análisis fitoquímico, determinación cualitativa y cuantitativa de flavonoides y lenbeckia hastulata (J. E. Sm) I. M. Johnst" de la zona de Yucay (Cusco). [Grade work]. [Cusco, Peru]: Universidad Nacional Mayor de San Marcos: 2016. 96p.

Jiménez CIE, Martínez EYC, Fonseca JG. Flavonoides y sus acciones antioxidantes. Rev Fac Med UNAM [Internet]. 2009 [cited 2021 Oct 28];52(2):73-5. Available from: https://www.medigraphic.com/pdfs/facmed/un-2009/ un092g.pdf

Guiance SH, Marino L, Isern DM, Coria ID, Irurzun I. Flavonoides: aplicaciones medicinales e industriales. Invenio: Revista de investigación académica [Internet]. 2019 [cited 2021 Oct 28];(40):11-27. Available from: http://sedici.unlp.edu.ar/ bitstream/handle/10915/113738/Documento_completo. pdf-PDFA.pdf?sequence=1\&isAllowed $=y$

Calle EE, Rodriguez C, Jacobs EJ, Almon ML, Chao A, McCullough ML, et al. The American Cancer Society Cancer Prevention Study II Nutrition Cohort: rationale, study design, and baseline characteristics. Cancer. 2002 Jan 15;94(2):500-511. DOI: https://doi.org/10.1002/ cncr.10197

Gonzalez Chavarro, C. F., Cabezas Gutiérrez, M., Pulido Blanco, V. C., \& Celis Ruiz, X. M. Amaryllidaceae: Potential Source of Alkaloids. Biological and Pharmacological Activities. Ciencia y Agricultura [Internet] 2020 [cited 2021 Oct 28];17(3):78-94. Available from: https://doi. org/10.19053/01228420.v17.n3.2020.11379

Rivero N, Gomez M, Medina J. Search for Bioactive Alkaloids in Hymenocallis Species: Pharmaceutical Biology. 2004;42:45. DOI: https://doi.org/10.1080/13880200490511774

Waller GR. Saponins: Chemistry and Pharmacology of Natural Products By K. Journal of the American Chemistry Society. 1996;118(35):8509-8509. DOI: https://doi.org/10.1021/ ja9553056

Ojeda CM, Ramos DA, Núñez IC. Cuantificación de fenoles y flavonoides totales en un extracto blando de flores de Calendula officinalis Linn. Orange Journal. 2020;2(3):20-31. DOI: https://doi.org/10.46502/issn.2710-995X/2020.3.02

López-Carreras N, Miguel M, Aleixandre A. Propiedades beneficiosas de los terpenos iridoides sobre la salud. Nutricion Clinica y Dietetica Hospitalaria [Internet]. 2012 [cited 2021 Oct 28]; 32(3):81-91. Available from: https:// digital.csic.es/bitstream/10261/101431/1/terpenos\%20 iridoides.pdf 
Benítez R, Ibarz Ribas A, Pagan i Gilabert J. Hidrolizados de proteína: procesos y aplicaciones. Acta bioquimica clinica latinoamericana [Internet]. 2008 [cited 2021 Oct 28];42(2):227-236. Available from: https://repositori.udl. cat/handle/10459.1/49268

SCRIBD, Identificación de Saponinas Marcha. https://es.scribd. com/document/373329382/Identificacion-de-SaponinasMarcha 2018 (accessed 28 October 2021).

Cardozo Pinzón, J. S., \& Gómez Barrera, M. Contribución al estudio fitoquímico del extracto etanólico de las hojas de Kalanchoe daigremontiana Raym. Revista de la Asociacion Colombiana de Ciencias Biologicas [Internet]. 2019 Jan [cited 2021 Oct 28];1(30): 74-83. Available from: https://www.revistaaccb.org/r/index.php/accb/article/ view/159/152

Reyes NM. Análisis de características diferenciales entre antocianinas y betacianinas en extractos de plantas mediante pruebas de color. Ambiociencias- Revista de divulgación científica [Internet]. 2018 Dec [cited 2021 Oct 28];25(16):38-48. Available from: http://revpubli.unileon. es/index.php/ambioc/article/view/5754/4438

Poma EM, Requis ER, Gordillo GC, Fuertes CM. Estudio fitoquímico y actividad antiinflamatoria de la Annona muricata L. (guanábana) de Cuzco. Ciencia e investigación [Internet]. 2011 Dec [cited 2021 Oct 28];14(2):29-33. Available from: https://revistasinvestigacion.unmsm.edu. pe/index.php/farma/article/view/3168

Vit P, Santiago B, Pérez-Pérez EM. Composición química y actividad antioxidante de pulpa, hoja y semilla de guanábana Annona muricata L. Interciencia [Internet]. 2014 [cited 2021 Oct 28];39(5):350-353. Available from: https:// www.redalyc.org/pdf/339/33930879008.pdf

Cunha HR, Cantuária P de C, Costa EVM da, Farias ALF, Miranda Júnior JP, Mota LJT, et al. SCREENING FITOQUÍMICO, ANÁLISE CITOTÓXICA E ANTIMICROBIANA DO EXTRATO DAS FOLHAS DE ANNONA MURICATA L. (1753) (ANNONACEAE) [Internet]. Científica Digital; 2021 [cited 2021 Oct 28]; 208-219. Available from: https://downloads. editoracientifica.org/articles/210303480.pdf

Hoyos Roldán AF, Mora Páez GA, Gómez Barrera M. Análisis fitoquímico preliminar y evaluación de la actividad biológica del extracto etanólico de las semillas de la guanábana (annona muricata l.). Revista de investigaciones Carmenta [Internet] 2018 [cited 2021 Oct 28]. Available from: https://repositorio.sena.edu.co/handle/11404/6759

Bravo A, Rivera C, Ale D, Huamán M, Muñoz H, Delmás R, et al. OBTENCIÓN DE PLAGUICIDAS NATURALES A PARTIR DE SEMILLAS DE CHIRIMOYA (Annona cherimolia Mill.) Y GUANÁBANA (Annona muricata L.). Revista Peruana de Química e Ingeniería Química [Internet]. 2010 Dec 31 [cited 2021 Oct 28];13(2):96-103. Available from: https:// revistasinvestigacion.unmsm.edu.pe/index.php/quim/ article/view/4714/3796

Dueñas Cely DP. Estudio fitoquímico y evaluación de la actividad citotóxica de un extracto de hojas de Annona muricata (Guanábana) frente a las líneas celulares MCF-7, 4T1, B16 y 3T3. [Grade work]. [Bogotá, Colombia]: Pontificia Universidad Javeriana: 2019. 56p.
Alegre A, lannacone J, Carhuapoma M, Alegre A, lannacone J, Carhuapoma M. TOXICIDAD DEL EXTRACTO ACUOSO, ETANOLICO Y HEXÁNICO de Annona muricata, Minthostachys mollis, Lupinus mutabilis, Y Chenopodium quinoa SOBRE Tetranychus urticae Y Chrysoperla externa. Chilean journal of agricultural \& animal sciences [Internet]. 2017 [cited 2021 Oct 28];33(3):273-284. Available from: http://dx.doi.org/10.4067/S0719-38902017005000705.

Matos Alejo MM. Evaluación del efecto pediculicida del extracto etanólico de las semillas de Annona muricata L. "guanábana" sobre Pediculus humanus capitis (piojo humano). [Grade work]. [Lima,Perú]: Universidad Nacional Mayor de San Marcos: 2013.

Acosta Vásquez RC, Díaz Peña BJI. Evaluación composicional, capacidad antioxidantes de pulpa y cáscara de la Annona muricata I. (Guanábana). [Grade work]. [Iquitos,Perú]: Universidad Nacional de la Amazonía Peruana: 2016. 150p.

Cardona Serrate F. Proteínas y aminoácidos. Propiedades físico-químicas y funcionales. Universitat Politècnica de València [Internet]. 2020 Jun 30 [cited 2021 Oct 28]. Available from: http://hdl.handle.net/10251/147138

Salinero C, Barreiro R, Regueira N, Vela P. TÉ, CATEQUINAS Y SALUD. Sociedad de Ciencia de Galicia [Internet]. 2018 [cited 2021 Oct 28];99:47-56. Available from: http://mol-en.scg.org.es/wp-content/ uploads/2019/05/Mol-18.pdf\#page =47

Mío Roque VM, Cunyarache Pangalima D. Formulación y Caracterización de un Filtrante a Partir de las Hojas de Guanábana (Annona Muricata L.). [Grade work]. [Lambayeque, Perú]: Universidad Nacional Pedro Ruiz Gallo: 2018. 108p.

Alvarado Mayor PN, Bautista Flores A. Propiedades medicinales de la annona muricata: una revisión de la literatura. [Grade work]. [Lima, Perú]: Universidad Científica del Sur: 2021. 21p.

Alvarado Tolentino C, Venegas Ojeda D. Sobrevida de pacientes con cáncer gástrico en el Perú, 2009-2010. Rev Panam Salud Publica [Internet]. 2015 [cited 2021 Oct 28];37(3):133-139. Available from: https:// scielosp.org/pdf/rpsp/2015.v37n3/133-139/es

Rivas-Morales C, Oranday-Cárdenas MA, VerdeStar MJ. Investigación en plantas de importancia médica [Internet]. OmniaScience Monographs; 2016 [cited 2021 Oct 28]. 452p. Available from: https://www.omniascience.com/books/index.php/ monographs/catalog/view/97/409/812-1 DOI: https:// doi.org/10.3926/oms.313 